\title{
PROMINENT SEGMENTS IN A FICTION TEXT AS A TRANSLATIONAL TASK
}

\author{
Roman R. Chaykovskiy \\ North-Eastern State University, Magadan, Russian Federation
}

\begin{abstract}
The article is devoted to analyzing the so-called prominent segments of a fiction text, which are understood as parts of the text in which the writer in the textual space of their prose work reaches the highest semantic, psychological and stylistic level, considerably exceeding the degree of writing skills reflected in other parts of the novel. The stylistic-comparative method is used as the main method of the research. This method is used in the analysis of translations of E.M. Remarque's Three Comrades into English, Polish, Russian and Ukrainian, which allows assessing the adequacy of prominent segments translation.

The author describes the prominent segments of the novel, which are characterized by an increased degree of semantic significance in the corresponding section of the text, a special filigree lingua-stylistic design and a semantic-stylistic difference from the near left and right context.

As a result of the research it is shown that the prominent segments of a fiction prosaic text require special attention from translators. It is revealed that in a significant part of the analyzed translations, the stylistic craftsmanship of E.M. Remarque was not recreated: the stylistic filigree of the segments examined is replaced by low-textual correspondences. Often translators use linguistic solutions of their predecessors. It is proved that the outstanding novel by E.M. Remarque Three Comrades needs new translations both into English and into three Slavic languages: Polish, Russian and Ukrainian.

Key words: convergence, E.M. Remarque, translation, prominent segment, fiction text, foregrounding category.

Citation. Chaykovskiy R.R. Prominent Segments in a Fiction Text as a Translational Task. Vestnik Volgogradskogo gosudarstvennogo universiteta. Seriya 2, Yazykoznanie [Science Journal of Volgograd State University. Linguistics], 2017, vol. 16, no. 3, pp. 18-29. (in Russian). DOI: https://doi.org/10.15688/jvolsu2.2017.3.2

УДК 81 '255.2

ББК 81.18

Дата поступления статьи: 17.04.2017

Дата принятия статьи: 15.05.2017
\end{abstract}

\section{РЕЛЬЕФНЫЕ СЕГМЕНТЫ ХУДОЖЕСТВЕННОГО ТЕКСТА КАК ПЕРЕВОДЧЕСКАЯ ЗАДАЧА}

\author{
Роман Романович Чайковский \\ Северо-Восточный государственный университет, г. Магадан, Российская Федерация
}

\begin{abstract}
Аннотация. В статье исследуются рельефные сегменты художественного текста, в которых писатель в текстовом пространстве прозаического произведения достигает смыслового, психологического и стилистического уровня, заметно превышающего степень мастерства, отразившегося на других участках романа. С использованием стилистико-сопоставительного метода на материале переводов романа Э.М. Ремарка «Три б товарища» на английский, польский, русский и украинский языки демонстрируется адекватность переводов рельефных сегментов исходному тексту.

Описаны рельефные сегменты романа, которые характеризуются повышенной степенью смысловой значимости на соответствующем участке текста, особым филигранным лингвостилистическим оформлением и семантико-стилистическим отличием от ближнего левого и правого контекстов.

В работе показано, что вершинные компоненты художественно-прозаического текста требуют от переводчиков особого внимания. Установлено, что в значительной части изученных переводов стилистическое мастерство Э.М. Ремарка не воссоздано: стилистическая филигранность рассмотренных сегментов замене-
\end{abstract}


на маловыразительными текстовыми соответствиями. Обосновано предположение о том, что переводчики использовали лингвостилистические решения своих предшественников. Доказано, что выдающийся роман Э.М. Ремарка «Три товарища» нуждается в новых переводах как на английский, так и на три славянских языка: польский, русский и украинский.

Ключевые слова: конвергенция, Э.М. Ремарк, перевод, рельефный сегмент, художественный текст, категория выдвижения.

Цитирование. Чайковский Р. Р. Рельефные сегменты художественного текста как переводческая задача // Вестник Волгоградского государственного университета. Серия 2, Языкознание. - 2017. - Т. 16, № 3. - С. 1829. - DOI: https://doi.org/10.15688/jvolsu2.2017.3.2

1

Всякий текст представляет собой некий континуум, ограниченный началом и концом, носит линейный характер и в европейской языковой традиции разворачивается слева направо. Составляющие текст элементы разных уровней имеют левый (кроме зачина) и правый (кроме концовки) контексты. Некоторые исследователи пишут также о горизонтальной структуре текста, которая создает общий фон движения содержания к адресату, и о структуре вертикальной, которая «насыщает каждоезвено горизонтальной структуры информационным содержанием... придавая тексту прагматический смысл» [Брандес, 2004, с. 126-127], позволяя «проникать» в текст на любом его участке (а не только в его начале), что обеспечивает читателю возможность перечитывать нужные или понравившиеся ему места.

Традиционно структурная схема текста представляется в виде ранжированных по объему текстовых элементов: предложение $\rightarrow$ абзац $\rightarrow$ глава $\rightarrow$ часть $\rightarrow$ текстовое целое. Кроме того, обычно в качестве особых элементов исследователи выделяют заглавие, эпиграф, зачин, концовку. Однако им приписывают, на наш взгляд, излишне большое значение. Например, Л.А. Ноздрина считает возможным обращать «внимание в тексте на три так называемые “сильные позиции”: заглавие, зачин и концовку (по И.В. Арнольд), а середину текста рассматривать как одну композиционную единицу текста, не членя ее на абзацы или другие составляющие» [Ноздрина, 2004, с. 37].

При таком подходе «середина текста» уравнивается с зачином и концовкой, что не соответствует ее большей значимости в общей структуре текста. «Середина текста», как правило, и есть его основная часть, но рас- сматривать ее как одну композиционную «единицу» также вряд ли правомерно, поскольку она составляет саму основу художественного произведения, которая, в свою очередь, может многообразно члениться на части, главы, сегменты, фрагменты и т. п.

Любой художественный текст (мы имеем в виду художественно-прозаический текст, и прежде всего текст романа как наиболее глубокого по содержанию и наиболее объемного по форме литературного жанра), являя собой некое развернутое в длину словесное пространство, от зачина до концовки неоднороден в аспекте своего содержания и стилистической формы, стилистического совершенства, экспрессивности, эмоциональности, динамизма повествования, концептуальной и психологической глубины и насыщенности. Эту изменчивость текста в процессе его развертывания можно сравнить с осциллограммой какого-либо процесса, зафиксировавшей его верхние точки, протяженные части и нижние отметки.

В данной работе нас будут интересовать те части художественно-прозаического текста, где автор достигает смыслового, психологического и стилистического уровня, который заметно превышает степень писательского мастерства, отразившегося на других участках конкретного романа. Подобные главы, эпизоды, фрагменты, выделяющиеся на фоне всего текста, имеются практически во всех великих романах (и не только в них), на каких бы языках они ни были написаны. Такие вершинные части содержатся в романах Л. Толстого и Ч. Диккенса, Фр. Саган и Г. Гарсиа Маркеса, Э. Хемингуэя и Э.М. Ремарка, представляя собой смысловую и стилистическую вершину текста, свидетельствующую о том, что повествование в романе достигает своего апогея, после которого текст возвра- 
щается в «спокойное» нарративное русло. Такие сегменты текста «взрывают» определенную «благостность» левого контекста и поднимают повествование на неожиданную для читателя ступень, которая захватывает его целиком, а затем нередко заставляет обращаться к этой части текста вновь и вновь. По аналогии с традиционно выделяемыми сильными позициями текста такие части можно характеризовать как его сверхсильные сегменты. Важно заметить, что они могут находиться в любом месте текстового пространства, хотя нередко располагаются ближе к его центральной части.

Мы называем такие сегменты текста (при отсутствии более удачного термина) peльефными, поскольку значение этого прилагательного - «выпуклый, выделяющийся, выступающий из некоего ряда» (см.: Крысин Л. П. Толковый словарь иноязычных слов. М. : Эксмо, 2005. С. 666) - отражает их особенности на фоне целого текста произведения.

Критериями для отнесения того или иного сегмента текста к рельефным являются, вопервых, повышенная степень его смысловой значимости на соответствующем участке текста; во-вторых, его особое филигранное лингвостилистическое оформление; в-третьих, заметное общее семантико-стилистическое отличие данного сегмента от ближнего левого и правого контекста.

\section{2}

Большое количество рельефных сегментов разного объема содержится в романах Э.М. Ремарка. Примером рельефности текста служит его роман «Три товарища» (1938). Одним из наиболее ярких макросегментов этого произведения является 16-я глава. В издании, на которое мы ссылаемся в этой статье (см.: Remarque), она занимает шестнадцать страниц (со 188-й по 204-ю), а весь роман насчитывает 383 страницы. Следовательно, названная глава располагается в центре текста, образуя своеобразный «перевал» между его началом и концовкой.

Глава начинается с абзаца о том, как Роберт Локамп, главный герой романа, собравшись уходить с пляжа в дом, где они сни- мали комнату с его возлюбленной Патрицией Хольман, которая себя в этот день плохо чувствовала и поэтому не пошла с ним к морю, вдруг видит бегущую к нему служанку хозяйки, машущую рукой и что-то кричащую ему, но из-за ветра и шума волн он не может понять, что случилось.

Последующие абзацы, включая содержащиеся в них диалоги героя со служанкой, хозяйкой, соседями, у которых есть телефон, местным врачом, приехавшим помочь Пат, приобретают все более экспрессивный характер, призванный передать чувства отчаяния, беспомощности и в то же время надежды на чудо, охватившие Роберта, увидевшего свою любимую в крови - у нее, страдавшей туберкулезом, началось кровотечение, и она продолжала кашлять кровью.

Внутри главы как рельефного макросегмента имеются рельефные сегменты меньшего объема. Один из них - абзац, содержащий описание страданий Патриции, начинающийся со слов Sie röchelte... и заканчивающийся фразой ...dann fiel sie schlapp zurück (Remarque, S. 189); другой - описание обстановки и людей в доме, откуда Роберт звонил в город, стараясь найти врача, ранее лечившего Пат. Когда ему это не удается, он вдруг вспоминает о своем друге Кестере и звонит ему. Тот обещает тут же поехать на поиски профессора. Этот сегмент отделяется от последующего таким микросегментом:

Vorbei. Vorbei? Die Welt stand stille. Der Spuck war aus. Ich lief zurück (Remarque, S. 191).

Ремарк (осознанно или неосознанно) использовал в этом месте романа ямбический размер. Семантический ореол ямба почти сто лет назад очертил Н. Гумилев: ямб «свободен, ясен, тверд и прекрасно передает человеческую речь, напряженность человеческой воли» [Гумилев, 1920, с. 58]. Эти пять написанных почти в телеграфном стиле предложений представляют собой ритмическую границу между начальной частью макросегмента и его основной частью, посвященной описанию поисков доктора Жаффе, рискованной езды Кестера на общем автомобиле трех друзей, названном ими «Карлом», и немногословному общению Кестера и Роберта. Выделен- 
ный микросегмент подчеркивает напряженность человеческой воли, которая проявляется в действиях героев романа.

Основная часть макросегмента также включает несколько сегментов. Первый из них - это речь Роберта, обращенная к больной Пат, начинающаяся фразой Wir sind alle $d a$ и заканчивающаяся предложением Jetzt ist alles gut (Remarque, S. 192).

Второй рельефный сегмент этой части открывается предложением Ich konnte es nicht mehr aushalten и закрывается фразой die Augen meines Freundes (Remarque, S. 193).

В третьем, удлиненном, рельефном сегменте описаны поиски доктора Жаффе, предпринятые Кестером.

Непосредственно за этим сегментом следует еще один рельефный сегмент - один небольшой абзац, посвященный смелой езде Кестера по городу в его стремлении как можно скорее выехать на шоссе. Найдя врача, Кестер спрашивает его, опасно ли положение Пат, и врач отвечает «да».

В последующем развитии текста этой главы рельефные сегменты идут почти подряд один за другим, образуя единый объемный рельефный сегмент, занимающий почти две страницы текста. В нем Ремарк изображает невероятно опасную ночную гонку Кестера, везущего врача для подруги своего товарища, ожидание Робертом спасения от своего друга (ощущение Роберта, что он слышит далекое жужжание какого-то насекомого, осознание того, что это звук далекого мотора, что это Кестер на их безотказном «Карле» летит сквозь ночь на помощь) и развязку этой ситуации - благополучное и своевременное прибытие Кестера с врачом к Роберту и Патриции (напряжение спадает, ночь, страх исчезают, впереди брезжит надежда, впереди спасение).

Автор этой статьи знает нескольких человек, далеко не сентиментальных, говоривших ему о том, что у них в этом месте романа каждый раз на глаза наворачиваются слезы. Известный специалист по немецкоязычной литературе Д. Затонский также писал, что при чтении этого сегмента текста у читателя комок подступает к горлу [Затонський, 1986, c. 20]. Такова сила подлинного искусства слова. Э.М. Ремарк своим романом доказал, что ему по плечу такие вершины мастерства, которые в мировой литературе доступны только великим.

Для целей нашей статьи в определенной мере применима категория выдвижения, описанная И.В. Арнольд. Выдвижение - это «наличие в тексте каких-либо формальных признаков, фиксирующих внимание на некоторых чертах текста и устанавливающих смысловые связи между элементами разных уровней или дистантными элементами одного уровня. Выдвижение задерживает внимание читателя на определенных участках текста и тем помогает оценить их относительную значимость, иерархию образов, идей, чувств» [Арнольд, 2010, с. 205]. В качестве одной из форм выдвижения И.В. Арнольд рассматривает конвергенцию, под которой она, вслед за М. Риффатером, понимает пучок стилистических приемов, объединенных общностью передаваемого смысла и стилистической функции. Конвергенция как один из видов выдвижения указывает на что-то важное для текста в целом, но занимает небольшой его отрезок [Арнольд, 2010, с. 196].

Отталкиваясь от идеи В.Б. Шкловского об энергии заблуждения как форме поиска истины [Шкловский, 1981, с. 9], мы можем говорить об энергии выдвижения лингвостилистических средств для повышения силы воздействия текста на читателя. Такую энергию выдвижения мы обнаруживаем и в приеме конвергенции, который характеризует прозу Э.М. Ремарка и способствует формированию рельефных сегментов.

В 16-й главе «Трех товарищей» конвергенция использована по методу матрешки меньшие конвергенционные участки входят в более крупные части, совместно усиливая степень выдвижения.

Перейдем к рассмотрению путей воссоздания рельефных сегментов из романа «Три товарища» в переводах на разные языки. В качестве материала для сопоставительного анализа мы взяли соответствующие сегменты из переводов на английский и польский языки, из трех переводов на русский язык и двух переводов на украинский язык.

3.1. Обратимся к анализу следующего сегмента: 
In diesem Augenblick verwandelte sich Karl in ein weißes Gespenst. Er sprang mit einem Satz vom Start und fegte los. Er zwängte sich durch, er fuhr mit zwei Rädern über den Bürgersteig, er jagte in falscher Richtung durch Einbahnstraßen, er suchte den kürzesten Weg aus der Stadt heraus (Remarque, S. 194).

Приведенный сегмент написан Ремарком мастерски. В нем обнаруживается пучок стилистических приемов, основанных на использовании лексических и синтаксических средств языка. Так, в абзаце доминируют лексические единицы, содержащие сему 'стремительность действия': существительные Augenblick, Satz, Start и глаголы sich verwandeln, springen, los fegen, sich zwängen, jagen. Выражению резкого начала движения «Карла» и его бешеной гонки по городу служит также синтаксис. В оригинале сегмент состоит из трех предложений - двух простых и одного сложносочиненного. Пятикратный повтор местоимения er, синтаксический параллелизм предложений, паратактическая структура сегмента подчеркивают стремительность продвижения машины по улицам, воспринимаемого читателем как неупорядоченный лет белого призрака - образное сравнение в первом предложении иррадиирует на весь последующий контекст сегмента.

Перевод на английский язык:

From that moment Karl was transformed into a flying white ghost. With a bound he leapt from the start and swept away. He forced a way through, rode with two wheels on the footway, dashed contrariwise up one-way streets, seeking the shortest way out of the city (Wheen, p. 245).

Первый переводчик Ремарка на английский язык А. Уин максимально полно передал содержание сегмента на денотативном уровне. Он воспользовался целым рядом английских глаголов с семой стремительности действия: to fly, to leap, to sweep, to dash. Однако уже в первом предложении он несколько затормаживает повествование - вместо одного из возможных более интенсивных соответствий словосочетанию in diesem Augenblick - instantly, in a trice, in a moment А. Уин прибегает к более статичному from that moment. К тому же значение глагола активного действия sich verwandeln он передает глаголом в страдательном залоге was transformed. Сложносочиненное предложение с повтором местоименного подлежащего в английском переводе передано простым распространенным предложением с однородными глагольными сказуемыми. Снятие повтора подлежащего и добавление причастного оборота was transformed заметно снижают экспрессивность сегмента в переводе на английский язык. Элементы стилистического выдвижения в этом переводе практически отсутствуют.

Перевод на польский язык:

W tej chwili Karl zmienił się w białe widmo. Ostrym zrywem wystartował i pomknął prez ulice. Prześlizgiwał się jak piskorz, przemykał dwoma kołami po chodniku, parł w odwrotnym kierunku ulicami o jednostronnym ruchu, szukał najkrótszej drogi z miasta (Grabowski, s. 363).

В переводе 3. Грабовского ощутимо стремление воссоздать присущий данному сегменту динамизм. Это удается переводчику, несмотря на добавления, которые мы обнаруживаем в его варианте: prez ulice, jak piskorz. На наш взгляд, указанные добавления вызваны не только некоторым давлением польского синтаксиса, но и желанием переводчика в какой-то мере воссоздать ритм ремарковского текста. Элиминация подлежащего во втором предложении и трансформация сложносочиненного предложения в ряд простых с однородными сказуемыми, осуществленные в рамках норм польской лингвостилистики, также способствуют воссозданию динамики описания. Использование 3. Грабовским стилистически сниженной формы parl от глагола przeć (буквально: «пёр») весьма удачно вписывается в контекст его перевода. Сегмент предстает перед польским читателем адекватным оригинальному тексту. Следовательно, мы можем утверждать, что в переводе на польский язык ощутимы попытки воссоздать приемы выдвижения, характерные для прозы Ремарка.

Переходя к сопоставлению оригинала с тремя русскими и двумя украинскими переводами, нельзя не упомянуть о тезисе М. Веллера, в соответствии с которым предшествующий перевод порой служит для последующих переводчиков неким подстрочником, на основе которого можно изготовить новый ва- 
риант перевода. М. Веллер пишет об этом так: «Когда читаешь два разных перевода одной и той же вещи - в прозе, я сейчас имею в виду, - кажется, будто переводчик кладет перед собой уже имеющиеся переводы и старается, чтобы ни одна фраза не совпадала хоть словом! - с тем, как она уже была переведена. И думаешь, что и сам неплохо мог бы быть переводчиком, имея уже один перевод - как подстрочник» [Веллер, 2008, c. 224]. К этим размышлениям известного прозаика можно добавить то, что текстамидонорами для переводчика могут быть не только предшествующие переводы на тот же язык, на который он переводит, но и переводы на другие языки. В свете сказанного роль переводов-открытий, то есть первых переводов того или иного произведения на другой язык, неизменно возрастает, поскольку их авторов нельзя обвинить в том, что они работали, опираясь на тексты уже существующих переводов.

Первый перевод романа «Drei Kameraden» на русский язык, опубликованный в 1939 г. в Риге газетой «Сегодня вечером» под заглавием «Три друга», был анонимным. Как известно, до этого в рижских издательствах и газетах были напечатаны на русском языке романы Э.М. Ремарка «Мансарда снов», «На Западном фронте без перемен» (два перевода), «Обратный путь». Все эти переводы, сделанные сразу после выхода оригинальных произведений, отличались хорошим качеством. Принципы перевода, которые были характерны для работы рижских переводчиков Ремарка 30-х гг. Г. Левина, А. Коссовича, Л. Мейерсона, в той или иной мере были реализованы и в переводе романа «Drei Kameraden». К ним можно отнести бережное отношение к форме оригинала, отсутствие «оглядки» на предшествующие переводы, стремление к максимально точной передаче содержания оригинального текста. Приведем соответствующий сегмент этого перевода:

В тот же момент «Карл» превратился в белый призрак. Одним прыжком он сорвался со старта и понесся вперед. Он пробивался сквозь все препятствия, он ехал двумя колесами по тротуару, он мчался в неправильном направлении по улицам, где движение производилось в одну сторону, он искал кратчайший путь из города (Аноним).
Забегая вперед, отметим, что только в рижском переводе полностью сохранен синтаксический параллелизм, выполняющий в этом отрывке оригинала важную функцию повышения динамизма повествования. Воссоздание в переводе данного синтактико-стилистического приема в значительной мере обеспечивает адекватность перевода и дает читателю возможность получить представление о синтаксической структуре оригинала. За исключением фразы он мчался в неправильном направлении по улицам, где движение производилось в одну сторону, отличающейся многословностью (вероятно, в словарном составе русского языка в конце тридцатых годов не было соответствия немецкому слову Einbahnstraße), перевод отражает все основные стилистические качества текста Ремарка, описанные нами выше. Прием конвергенции как один из видов стилистического выдвижения оказался весьма удачно примененным в этом анонимном тексте. Перевод 1939 г. наглядно демонстрирует тот факт, что соблюдение переводчиком синтактико-стилистической структуры подлинника весьма часто дает лучшие результаты, нежели необоснованная ее трансформация.

Доказательством сказанного может служить перевод И. Шрайбера и Л. Яковенко 1958 г::

В ту же секунду «Карл» превратился в белое привидение. Он рванулся с места и понесся. Он обгонял всех, наезжал колесами на тротуары, мчался в запрещенном направлении по улицам с односторонним движением. Машина рвалась из города, пробивая себе кратчайший путь (Шрайбер, Яковенко, с. 227).

Переводчики увеличивают число предложений, разбивая сложносочиненное предложение оригинала на два простых. При этом в первом из них присутствуют три однородных сказуемых (обгонял, наезжал, мчался), а второе осложнено деепричастным оборотом (пробивая себе). Экспрессивность и динамизм текста перевода по сравнению с текстом подлинника заметно снижены. Первая часть сложносочиненного предложения $E r$ zwängte sich durch передана как Он обгонял всех, что несколько сужает ее смысл. Возни- 
кает впечатление, что переводчики стремились быть точными в воссоздании словника текста и пренебрегали особенностями его синтаксиса.

Переводческую стратегию, аналогичную описанной, мы обнаруживаем и в переводе Ю. Архипова (1989 г.):

И в то же мгновение «Карл» превратился в белый призрак, вихрем полетевший по дороге. Он обгонял всех, вылетая подчас двумя колесами на тротуары, мчась в поисках кратчайшего пути из города в запрещенном направлении по улицам с односторонним движением (Архипов, с. 191).

Ю. Архипов утяжеляет синтаксис своего перевода, трансформируя три предложения оригинала в два и снижая степень динамизма текста: в первом предложении он использует причастный оборот с добавлением существительного вихрь (вихрем полетевший по дороге), а во второе вводит два деепричастных оборота (вылетая... и мчась...), один из которых включает пятнадцать слов. В результате столь существенного изменения синтаксической структуры текст теряет и экспрессивность, и динамизм, присущие ему в оригинале. В наших предыдущих работах уже было показано, что синтаксис способен придавать тексту такие качества, которые обычно обеспечиваются соответствующим подбором лексики, и тем самым позволяет писателю обходиться меньшим количеством слов; это характерно именно для прозы Ремарка [Чайковский, 1980, с. 14].

Отметим, что в переводе Ю. Архипова использована фраза Он обгонял всех, которая встречается в переводе И. Шрайбера и Л. Яковенко.

Стратегия выдвижения в обоих переводах оказалась реализованной лишь отчасти.

Рассмотрим переводы на украинский язык. Первый перевод, выполненный М. Дятленко и А. Плютом, увидел свет в 1986 г., а второй, принадлежащий Д. Радиенко, был издан в 2007 году.

В ту ж мить «Карл» перетворився на білого привида. Він рвонув з місця і помчав, як вітер. Він протискувався між машинами, наїжджав колесами на тротуари, гнав у забороненому напрямі вулицями одностороннього руху, вишукуючи найкоротший шлях за місто (Дятленко, Плют, с. 385).
В переводе М. Дятленко и А. Плюта на денотативном уровне содержание исходного текста воссоздано вполне адекватно ремарковскому тексту, однако в нем не передан семантически и стилистически значимый параллелизм коротких предложений в составе сложносочиненного, вследствие чего перевод лишился свойственной оригиналу подчеркнутости каждого отдельного «действия» автомобиля. Заключительный деепричастный оборот также не способствует воссозданию идеи стремительности движения. Неоправданным представляется добавление переводчиками сравнения як вітер - оно привносит в перевод элемент банализации.

Тієї ж миті «Карл» обернувся на білу примару. Він рвонув із місця і помчав. Він обганяв усіх, наїздив колесами на тротуари, мчав у забороненому напрямку по вулицях з однобічним рухом. Машина рвалася з міста, торуючи собі найкоротший шлях (Радієнко, с. 218).

Перевод Д. Радиенко, если судить только по приведенному сегменту, ничего нового в воссоздание ремарковского стиля не вносит. Переводчик необоснованно отказывается от воссоздания синтаксиса оригинала, использует завершающий деепричастный оборот, утяжеляющий финальное предложение. Обращает на себя внимание тот факт, что и в этом украинском переводе вновь появляется фраза Він обганяв усіх, дословно повторяющая далеко не оптимальные варианты переводов на русский язык 1958 и 1989 годов. В целом же перевод этого сегмента на украинский язык фактически повторяет лексико-синтаксическую структуру перевода на русский язык, выполненного И. Шрайбером и Л. Яковенко.

3.2. Рамки статьи не позволяют нам столь же подробно рассмотреть в сопоставительном плане многие другие сегменты оригинала и его переводов. Поэтому мы проанализируем лишь еще один сегмент текста, в котором так же ярко проявляется стилистическое мастерство Ремарка:

Die Reifen begannen zu knarren - zu zischen zu heulen - zu pfeifen - der Motor gab jetzt alles her, was er hatte. Köster lag nach vorn geduckt, sein Körper war ein einziges gewaltiges Ohr, ein Filter, der das Donnern und Pfeifen auf Geräusche durchsiebte und auf der Lauer lag nach jedem winzigen Neben- 
laut, jedem verdächtigen Schurren und Schleifen, das die Panne und den Tod bergen konnte (Remarque, S. 195).

В оригинале сегмент состоит из двух сложных предложений. Первое содержит экспрессивное сказуемое, состоящее из четыpex инфинитивов к глагольной форме begannen: knarren, zischen, heulen, pfeifen. Все эти глаголы относятся в данном контексте к шинам автомобиля, производящим при движении по шоссе различные звуки. Их объединяет одна и та же сема - 'производить шум'. Если проанализировать цепочку лексем в начале первого сложноподчиненного предложения Die Reifen begannen zu knarren$z u$ zischen - zu heulen - zu pfeifen, представляющую собой яркий пример стилистической конвергенции, то можно обнаружить определенную закономерность в соположении слов: сначала идет глагольная форма begannen, за которой следует инфинитив с тем же опорным гласным - knarren. Затем корневые гласные сменяются на $i$ (zischen) и еu (heulen), а заканчивается ряд рифмой к начальному слову предложения: Reifen - pfeifen, что не только закольцовывает эту стилистически совершенную фразу, но и соединяет предмет (шины) с основным звуком, издаваемым им при очень быстрой езде автомобиля, - свистом.

Во втором предложении Ремарком употреблены нехарактерные для немецкого синтаксиса пары существительных (das Donnern und Pfeifen, Schurren und Schleifen, die Panne und den Tod), соразмерно наполняющие микропространство сегмента. Приведем в той же последовательности семь переводов этого сегмента на четыре языка с краткими комментариями.

Перевод на английский язык:

The tyres began to snarl, to hiss, to whine, to whistle; the engine was giving all that was in it. Köster lay, his whole being intent on what was ahead, his body one mighty ear, a filter sifting the thunder and the whistling for every tiniest other noise, for every suspicious purr or knock or drag that might mean a puncture and death (Wheen, p. 246).

Переводчик передает этот сегмент с применением привычной для него стратегии. Он привносит в текст от себя фразу his whole being intent on what was ahead, вместо парных су- ществительных Schurren und Schleifen использует три: purr or knock or drag, заменяя при этом соединительный союз und разделительным $o r$, и снижает выразительность заключительной фразы, употребляя вместо глагола bergen ceмантически размытый глагол mean.

Перевод на польский язык:

Opony zaczęły trzeszczeć, syczeć, wyć, gwizdać. Silnik dawał z siebie wszystko, na co było go stać. Köster leżał na kierownicy, wychyclony ku przodowi, ciało jego było jednym olbrzymim uchem, filtrem, przez który przesiewał huk i gwizd i rozdzielał je na oddzielne tony. Czatował na najlżejszy obcy odgłos, na podejrzane szurnięcie czy poślizg, który mógł kryć w sobie defekt i pewną smierć (Grabowski, s. 364-365).

Польский переводчик также прибегает к добавлениям: wychyclony ku przodowi; rozdzielat je na oddzielne tony. Первое из них, как представляется, излишне, поскольку человек за рулем автомобиля при езде на высокой скорости обычно наклоняется вперед. Второе также носит необязательный характер и противоречит тенденции к сжатости описаний в прозе Ремарка. Слово defekt не покрывает семантического объема немецкого слова die Panne.

Перевод на русский язык:

Шины начали трещать, выть, шипеть, свистеть мотор давал все, на что он был способен. Кестер сидел, подавшись вперед. Его тело превратилось в одно единственное огромное ухо, в фильтр, просеивающий гром и свист в отдельные шумы и подстерегающий любой ничтожный побочный звук, каждый подозрительный шорох и скольжение, которые могли скрывать в себе катастрофу и смерть (Аноним).

Рижский перевод 1939 г. тоже не свободен от неточностей. Вряд ли можно признать удачным соответствие knarren - трещать. Шины, как правило, не трещат, а скрипят, и употребленный Ремарком глагол это значение в себе несет. Вызывает в данном контексте сомнение и уместность употребления слова скольжение. Обращает на себя внимание добавление одинакового элемента в этом переводе и в переводе на польский язык: 8 omдельные шумы и па oddzielne tony. Вряд ли в этом случае можно говорить о заимствовании переводческого решения. Возможно, мы имеем дело с идентичным восприятием пе- 
реводчиками исходной фразы, которая, на их взгляд, требовала такого уточнения.

Покрышки скрипели, шипели, завывали, свистели - мотор отдавал теперь всю свою мощь. Кестер пригнулся к рулю, его тело превратилось в огромное ухо, в фильтр, просеивающий гром и свист мотора и шасси, чутко улавливающий малейший звук, любой подозрительный скрип и скрежет, в которых могли таиться авария и смерть (Шрайбер, Яковенко, с. 228).

В переводе И. Шрайбера и Л. Яковенко нельзя не отметить почти дословного повтора рижского перевода: Его тело превратилось в одно единственное огромное ухо, в фильтр,

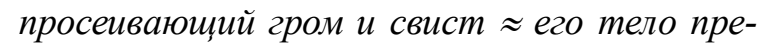
вратилось в огромное ухо, в фильтр, просеивающий гром и свист. При этом И. Шрайбер и Л. Яковенко опускают перевод слова einziges («единственный»), но добавляют уточнение: мотора и шасси. Трудно предположить, что И. Шрайбер и Л. Яковенко имели возможность пользоваться переводом из газеты «Сегодня вечером», хотя полностью исключить вероятность этого нельзя.

Шины визжали, шипели, выли, свистели мотор отдавал теперь все, на что был способен. Кестер весь вытянулся вперед, его тело превратилось в одно огромное ухо, в некий фильтр, просеивающий и грохот и посвист внутри и снаружи, чутко улавливающий малейший шорох, любой подозрительный скрежет и скрип, чреватый аварией, смертью (Архипов, с. 192).

Ю. Архипов, по-видимому, стремился сделать свой перевод непохожим на перевод И. Шрайбера и Л. Яковенко, поэтому он использует синонимы слов и фраз, содержащихся в переводе его предшественников. Ср.: покрышки - шины; пригнулся к рулю - весь вытянулся вперед; гром и свист - грохот и посвист. У И. Шрайбера и Л. Яковенко скрип и скрежет, у Ю. Архипова скрежет и скрип. И. Шрайбер и Л. Яковенко вносят излишнее добавление мотора и шасси, в то время как Ю. Архипов в этом же месте ставит столь же ненужное словосочетание внутри и снаружи. В отличие от И. Шрайбера и Л. Яковенко Ю. Архипов в одном месте повторяет союз: и грохот и посвист, в другом - опускает его: аварией, смертью.
Итак, в переводах на русский язык 1958 и 1989 гг. не ощущается желания переводчиков максимально близко воссоздать особенности словоупотребления Ремарка и семантику его синтаксиса, а улавливается стремление во что бы то ни стало написать что-то по-своему или добавить в текст какие-либо ненужные элементы.

Перевод на украинский язык:

Шини рипіли - сичали - вищали - свистіли... Тепер мотор працював на повну потужність. Кестер сидів, нахилившись до керма, усе його тіло перетворилося на величезне вухо, на фільтр, що проціджував увесь цей гуркіт і свист, чатуючи на кожен побічний звук, кожне підозріле шарудіння й шурхіт, в яких могла критися аварія і смерть (Дятленко, Плют, с. 386).

Украинский перевод 1986 г. отличается бережным отношением к воссозданию стилистики оригинала. Решение переводчиков завершить первое предложение многоточием и оформить следующее в виде самостоятельного простого можно признать вполне соответствующим как стилю Ремарка, так и требованиям стилистики украинского языка. Однако в их переводе обнаруживается добавление, которое имеет место в переводе И. Шрайбера и Л. Яковенко: мотора й шасі $=$ мотора и шасси. Можно высказать предположение, что М. Дятленко и А. Плют пользовались переводом на русский язык 1958 г. как текстом-донором и решили, вслед за своими российскими коллегами, несколько подробнее разъяснить читателю описываемую Ремарком ситуацию.

Покришки рипіли, шипіли, завивали, свистіли - мотор віддавав тепер усю свою силу. Кестер схилився до керма, його тіло обернулося на велетенське вухо, на фільтр, що просіював гуркіт та свист мотора й шасі, сторожко ловив кожне підозріливе рипіння та скрегіт, у яких могла чаїтись аварія й смерть (Радієнко, с. 220).

Автор украинского перевода 2007 г. Д. Радиенко в еще большей степени, видимо, использовала перевод И. Шрайбера и Л. Яковенко. Ее перевод в значительной мере повторяет русский перевод 1958 года. Складывается впечатление, что Д. Радиенко переписала перевод И. Шрайбера и Л. Яковенко соответствующими украинскими словами, опустив 
лишь добавление, внесенное авторами русского перевода (улавливающий малейший звук), но оставив слова мотора й шасі.

Анализ трех русских и двух украинских переводов позволяет сделать вывод о том, что возможны, по меньшей мере, три пути выполнения нового перевода уже переведенного прозаического произведения. Первый вариант состоит в том, чтобы, как писал М. Веллер, ни в коем случае не допустить совпадений с уже существующим переводом. При втором варианте новый переводчик не стремится во чтобы то ни стало избежать повторов переводческих решений предшественника и время от времени использует его находки. Третий вариант заключается в том, что перевод выполняется без обращения к уже существующим переводным версиям. Как показывает практика, и в этом случае в новом переводе также окажется немало дословных совпадений с имеющимися переводами. Это объясняется тем, что разные переводчики, как правило, стремятся следовать за текстом оригинала, то есть иноязычный текст словно ведет рукой переводчика. Они выбирают схожие, а порой и идентичные пути решения переводческих задач, поскольку как носители одного и того же языка владеют в какой-то мере общим словарным запасом, а зачастую и литературным опытом. Как писал еще в 1963 г. в своей известной статье «Плагиат или самостоятельный перевод? (Об одной судебной экспертизе)» Я.И. Рецкер, «в какой-то мере переводы одного и того же произведения должны совпадать» [Рецкер, 1963, с. 43]. В другом месте его статьи читаем: «Сколько бы переводчиков ни переводили одно и то же произведение, если они будут переводить правильно, они вынуждены будут пользоваться одними и теми же эквивалентными соответствиями» [Рецкер, 1963, с. 45].

С учетом выведенного Я.И. Рецкером закона все случаи совпадений в проанализированных переводах могут носить вынужденный или случайный характер, поэтому наши комментарии о таких случаях представляют собой предположения и допущения. Для более определенных выводов о степени самостоятельности того или иного перевода потребуется сплошной анализ текстов оригинала и соответствующих переводов.
4

Подводя итог рассмотренному в статье материалу, можно подчеркнуть следующее.

Рельефные сегменты - это вершинные компоненты художественно-прозаического текста, содержательная и лингвостилистическая субстанция которых является отражением животворной интеллектуальной и творческой силы писателя. В упоминавшейся нами книге «Энергия заблуждения» В. Шкловский писал, что есть вес смысла и вес строки [Шкловский, 1981, c. 349]. Рельефные сегменты текста этот вес смысла и вес строк значительно увеличивают. Переводчик должен уметь улавливать это преумножение веса смысла и веса строк и стремиться передать это ощущение читателю той же возросшей мерой.

Однако переводчики далеко не всегда улавливают рельефный характер переводимых сегментов и воссоздают их, не прибегая к приемам стилистического выдвижения, как нейтральные в стилистическом плане фрагменты текста. Тем самым они сглаживают стиль оригинала, лишая читателя возможности насладиться языковым мастерством писателя.

Для проанализированных переводов характерны различные добавления в тех местах сегментов, где они не являются необходимыми. Повторы ненужных добавлений в переводах на один и тот же язык и на близкородственный язык свидетельствуют о вероятном использовании уже готовых переводов в качестве вторичных текстов-доноров.

Выявленные случаи межъязыковых повторов позволяют утверждать, что текстыдоноры используются и в тех случаях, когда в них нет явной необходимости.

Рассмотренные сегменты оригинала и семи переводов романа Э.М. Ремарка на четыре языка подтверждают необходимость создания новых переводов этого шедевра, которые были бы свободны от произвола переводчиков и максимально полно воссоздавали бы всю глубину, все богатство и изящество ремарковской прозы.

\section{СПИСОК ЛИТЕРАТУРЫ}

Арнольд, И. В. Семантика. Стилистика. Интертекстуальность / И. В. Арнольд. - М. : ЛИБРОKOM, 2010. -448 c. 
Брандес, М. П. Стилистика текста. Теоретический курс / М. П. Брандес. - М. : Прогресс-Традиция : ИНФРА-М, 2004. - $416 \mathrm{c}$.

Веллер, М. Слово и профессия / М. Веллер. M. : АСТ МОСКВА, 2008. $-542 \mathrm{c}$.

Гумилев, Н. Переводы стихотворные / Н. Гумилев // Принципы художественного перевода. Петроград : Гос. изд-во, 1920. - С. 54-59.

Затонський, Д. Перечитуючи Ремарка / Д. Затонський // Твори в двох томах. Т. 1. На Західному фронті без змін. Три товариші / Е. М. Ремарк. Київ : Дніпро, 1986. - С. 5-33.

Ноздрина, Л. А. Поэтика грамматических категорий / Л. А. Ноздрина. - М. : ТЕЗАУРУС, 2004. $212 \mathrm{c}$

Рецкер, Я. И. Плагиат или самостоятельный перевод? (Об одной судебной экспертизе) / Я. И. Рецкер // Тетради переводчика. - М. : Изд-во ИМО, 1963. - Вып. 1.- С. 42-64.

Чайковский, Р. Р. Синтаксис и стиль / Р. Р. Чайковский. - Хабаровск : ХГПИ, 1980. - 64 с.

Шкловский, В. Б. Энергия заблуждения. Книга о сюжете / В. Б. Шкловский. - М. : Сов. писатель, 1981. $-351 \mathrm{c}$

\section{ИСТОЧНИКИ}

Аноним - Ремаркь, Э. М. Три друга / Э. М. Ремаркъ ; [переводчик не указан] // Сегодня вечером [Рига]. - 1939. - 7 марта - 18 июля (№ 54-160).

Архипов - Ремарк, Э. М. Три товарища / Э. М. Ремарк ; пер. с нем. Ю. Архипова. - М. : Худож. лит., 1989. - 368 с.

Дятленко, Плют-Ремарк, Е. М. Три товариші / Е. М. Ремарк ; переклад М. Дятленка та А. Плюта // Твори в двох томах. Т. 1. На Західному фронті без змін. Три товариші / Е. М. Ремарк. - Київ : Дніпро, 1986. - C. 195-572.

Радієнко - Ремарк, Е. М. Три товариші / Е. М. Ремарк ; переклад Д. Радієнко. - Харків : Фоліо, 2007. - 430 c.

Шрайбер, Яковенко - Ремарк, Э. М. Три товарища / Э. М. Ремарк ; пер. с нем. И. Шрайбера и Л. Яковенко. - М. : Гослитиздат, 1958. $431 \mathrm{c}$.

Grabowski-Remarque, E. M. Trzej towarzysze / E. M. Remarque ; thumaczył Zbigniew Grabowski. Warszawa : Czytełnik, 1968. - 704 s.

Remarque - Remarque, E. M. Drei Kameraden. Roman. Mit einem Nachwort von Tilman Westphalen / E. M. Remarque. - Köln : Kiepenheuer \& Witsch, 1998. $-398 \mathrm{~S}$.

Wheen - Remarque, E. M. Three Comrades /E. M. Remarque; translated by A. W. Wheen. - N. Y. : Fawcett Columbine, 2010. $-480 \mathrm{p}$.

\section{REFERENCES}

Arnold I.V. Semantika. Stilistika. Intertekstualnost [Semantics. Stylistics. Intertextuality]. Moscow, LIBROKOMPubl., 2010. 448 p.

Brandes M.P. Stilistika teksta. Teoreticheskiy kurs [Text Stylistics. A Theoretical Course]. Moscow, Progres-Traditsia, INFRA-M Publ., 2004. 416 p.

Veller M. Slovo i professiya [Word and Profession]. Moscow, AST MOSKVA Publ., 2008. $542 \mathrm{p}$.

Gumilev N. Perevody stikhotvornye [Poetry Translations]. Printsipy khudozhestvennogo perevoda [Principles of the Literary Translation]. Petrograd, Gos. izd-vo, 1920, pp. 54-59.

Zatonskiy D. Perechituyuchi Remarka [Rereading Remarque]. Remarque E.M. Tvori v dvokh tomakh. T. 1. Na Zakhidnomu fronti bez zmin. Tri tovarishi [Works in Two Volumes. Vol. 1. All Quiet on the Western Front. Three Comrades]. Kyiv, Dnipro Publ., 1986, pp. 5-33.

Nozdrina L.A. Poetika grammaticheskikh kategoriy [Poetics of Grammar Categories]. Moscow, Tezaurus Publ., 2004. 212 p.

Retsker Ya.I. Plagiat ili samostoyatelnyy perevod? (Ob odnoy sudebnoy ekspertize) [Plagiarism or an Independent Translation? (On a Judicial Examination)]. Tetradi perevodchika [Translator's Notebooks]. Moscow, Izd-vo IMO, iss. 1, pp. 42-64.

Chaykovskiy R.R. Sintaksis $i$ stil [Syntax and Style]. Khabarovsk, KhGPI Publ., 1980. 64 p.

Shklovskiy V.B. Energiya zabluzhdeniya. Kniga o syuzhete [Energy of Delusion. A Book on Plot]. Moscow, Sovetskiy pisatel Publ., 1981. 351 p.

\section{SOURCES}

Remark E.M. Tri druga [Three Friends]. Anonymous Translator. Segodnya vecherom [Tonight], 1939, 7 March - 18 July (no. 54-160).

Remark E. M. Tri tovarishcha [Three Comrades]. Transl. by Yu. Arkhipov. Moscow, Khudozh. lit. Publ., $1989.368 \mathrm{p}$.

Remark E.M. Tri tovarishi [Three Comrades]. Transl. by M. Dyatlenko, A. Plyut. Remarque E.M. Tvori v dvokh tomakh. T. 1. Na Zakhidnomu fronti bez zmin. Tri tovarishi [Works in Two Volumes. Vol. 1. All Quiet on the Western Front. Three Comrades]. Kyiv, Dnipro Publ., 1986, pp. 195-572.

Remark E.M. Tri tovarishi [Three Comrades]. Transl. by D. Radienko. Kharkiv, Folio Publ., 2007. $430 \mathrm{p}$.

Remark E.M. Tri tovarishi [Three Comrades]. Transl. by I. Shrayber, L. Yakovenko. Moscow, Goslitizdat Publ., 1958. 431 p. 
Remarque E.M. Trzej towarzysze [Three Comrades]. Transl. by Zbigniew Grabowski. Warszawa, Czyteinik, 1968. $704 \mathrm{p}$.

Remarque E.M. Drei Kameraden. Roman. Mit einem Nachwort von Tilman Westphalen [Three mates.
Novel. With an afterword by Tilman Westphalen]. Köln, Kiepenheuer \& Witsch, 1998. 398 p.

Remarque E.M. Three Comrades. Transl. by A.W. Wheen. N. Y., Fawcett Columbine, 2010. $480 \mathrm{p}$.

\section{Information about the Author}

Roman R. Chaykovskiy, Doctor of Sciences (Philology), Professor, Department of Foreign Languages and Literatures, North-Eastern State University, Portovaya St., 13, 685000 Magadan, Russian Federation, romantch@magadan.ru, http://orcid.org/0000-0003-2010-4571

\section{Информация об авторе}

Роман Романович Чайковский, доктор филологических наук, профессор кафедры зарубежной филологии, Северо-Восточный государственный университет, ул. Портовая, 13, 685000 г. Магадан, Российская Федерация, romantch@magadan.ru, http://orcid.org/0000-0003-2010-4571 